Article

\title{
Learners' Voices in Inclusive Education Policy Debates
}

\author{
Antonella Mangiaracina, Anthoula Kefallinou (1), Mary Kyriazopoulou and Amanda Watkins *
}

European Agency for Special Needs and Inclusive Education, Østre Stationsvej 33, 5000 Odense C, Denmark; antonella@european-agency.org (A.M.); anthoula@european-agency.org (A.K.); mary@european-agency.org (M.K.)

* Correspondence: amanda@european-agency.org

Citation: Mangiaracina, A.;

Kefallinou, A.; Kyriazopoulou, M.;

Watkins, A. Learners' Voices in Inclusive Education Policy Debates. Educ. Sci. 2021, 11, 599. https:// doi.org/10.3390/educsci11100599

Academic Editors: Michael Shevlin and Richard Rose

Received: 16 July 2021

Accepted: 24 September 2021

Published: 30 September 2021

Publisher's Note: MDPI stays neutral with regard to jurisdictional claims in published maps and institutional affiliations.

Copyright: (c) 2021 by the authors. Licensee MDPI, Basel, Switzerland. This article is an open access article distributed under the terms and conditions of the Creative Commons Attribution (CC BY) license (https:/ / creativecommons.org/licenses/by/ $4.0 /)$.
Abstract: Although the idea of including learners in policy-making is gaining ground, their voices still seem to be marginalised. This article focuses on the issue of learners' voices in inclusive education policy debates. It begins by discussing main policy developments, arguments and key issues around learner voice and participation. It then draws on different aspects of work by the European Agency for Special Needs and Inclusive Education (the Agency) that has directly involved young people in exchanges with policy-makers and decision-makers responsible for developing and implementing policy for inclusive education. This includes four European "Hearings" (in 2003, 2007, 2011 and 2015), involving over 300 young people. It also includes workshops with learners in Cyprus and Poland as part of the European Commission's Directorate-General for Structural Reform Support Programme activities. In the Agency's work, learners with a range of learning needs from across Europe shared their views on their right to education (access), their rights in education (learning and participation) and their rights in wider society (achievement). Key messages from learners included the importance of barrier-free schools, raising awareness, changing attitudes and combating stereotypes to support their longer-term social inclusion and ensure they are able to become full citizens in their local communities. Building on these messages, the article concludes with some important considerations for future work and recommends positioning learners as key agents in policy debates for inclusive education.

Keywords: learners' voices; inclusive education; policy debates

\section{Introduction}

There is an increasing focus and body of evidence on the importance and effect of young learners' voices in shaping school practice [1-3]. Listening to learners is recognised as a main factor that promotes the change process in schools $[4,5]$. The Global Education Monitoring Report 2020 [6] affirms that learners must be at the centre of everything schools and the entire education system do. This means learners' voices must be heard in policymaking debates and must shape practice that directly affects them. Therefore, practitioners', researchers' and policy-makers' work must fully respect and take account of learners' views, experiences and opinions [7].

This article focuses on the issue of learners' voices in inclusive education policy debates. It adopts the position of the European Agency for Special Needs and Inclusive Education (the Agency), viewing inclusive education as a human rights issue and an approach towards a more inclusive and equitable society. The Agency's vision for inclusive education systems is to ensure that "all learners of any age are provided with meaningful, high-quality educational opportunities in their local community, alongside their friends and peers" [8] (p. 1).

Guided by this vision, the article addresses two main questions:

1. How has the idea of listening to learners' voices evolved within European and international guiding principles documents?

2. How can learners' voices be included in inclusive education policy debates and other decision-making processes? 
Section 2 of this article provides an overview of the evolution of the concept of learner voice in the policy context. It discusses key policy developments at European Union (EU) and international levels that protect and promote children's and young peoples' voices and illuminates several issues and complexities. This brief overview covers policy documents that reflect EU and international policy debates over the last 30 years. Section 3 of the article outlines how the Agency has sought to involve learners in policy discussions. Section 4 presents findings and key messages from learners who have shared their views in policy fora.

The Agency is an independent organisation that acts as a platform for collaboration for the ministries of education in its 31 member countries. It focuses on supporting the development of inclusive education systems to ensure every learner's right to inclusive and equitable educational opportunities. It does this by combining the perspectives of policy, practice and research to provide member countries and stakeholders at the European level with evidence-based information and guidance and support on implementing inclusive education. The Agency's organisational set-up (member countries and their networks) and work focus place it in a unique position to directly involve learners in policy debates.

In discussing the issue of young voices in inclusive education debates, this article draws on two aspects of Agency work that directly involved young people with and without special educational needs and/or disabilities in exchanges with policymakers and decision-makers responsible for developing and implementing policy for inclusive education:

- Four European "Hearings" involving over 300 young people, held in 2003, 2007, 2011 and 2015;

- Consultation workshops with learners in Cyprus and Poland as part of the European Commission's Directorate-General for Structural Reform Support (DG REFORM) Structural Reform Support Programme (SRSP) activities.

\section{The Evolution of Learners' Voices in European and International Policy Documents}

Learners' voices is a cross-cutting topic intertwined with the general evolution of children's rights. This article uses the expressions "learners' voices" and "children's voices" interchangeably. Some official documents consulted for this article focus on a broad spectrum of topics, not only education. Therefore, in some cases, they use "children" to indicate young people enrolled in formal education, whereas "learners" refers to children who are not only agents in formal education, but also future citizens who need to be prepared for participation in democratic life and able to interact with other environments where they may participate and express their views. Participation in community life is a fundamental human right to which children are entitled.

The children's rights approach, which includes children's participation through policyand decision-making, has been advocated for decades. However, it proved challenging to put into practice due to the marginal and passive role of children and childhood in most 20th-century societies and debates. In 1959, the United Nations (UN) General Assembly adopted the Declaration of the Rights of the Child [9], which defines children's rights. However, in the international policy framework regarding children's voices, the UN Convention on the Rights of the Child (UNCRC) is the first forward-looking policy document advocating for children's rights. It states:

States Parties shall assure to the child who is capable of forming his or her own views the right to express those views freely in all matters affecting the child, the views of the child being given due weight in accordance with the age and maturity of the child.

For this purpose, the child shall in particular be provided the opportunity to be heard in any judicial and administrative proceedings affecting the child, either directly, or through a representative or an appropriate body, in a manner consistent with the procedural rules of national law. [10] (Article 12). 
The adoption of the UNCRC in 1989 and its entry into force in 1990 represent a milestone for children's rights. It acknowledged children's civil and political rights and was the very first legally binding international instrument for protecting children's rights. Before this-and even a decade later-policy documents considered children not as agents, but as "passive subjects" needing protection and care. The shift from "legal object" to "legal person" is therefore the turning point in advocating for children's human rights.

After the UNCRC, the Charter of Fundamental Rights of the European Union [11] —ratified in 2000, with entry into force in 2009-is the next major policy document that states children's right of expression on "matters which concern them in accordance with their age and maturity" (ibid., Article 24). In the period between the UNCRC and the Charter, other European and international policy documents [12-14] refer to promoting and protecting children's rights but only in a general way. They do not explicitly mention listening to children's voices. The child is a juridical subject with some sort of "passive" rights. The exercise of those rights is mentioned in administrative and judicial proceedings affecting them.

General comment No. 12 (2009) on the right of the child to be heard [15] is a further development in the framework of children's human rights. In it, the Committee on the Rights of the Child elaborates on the scope of Article 12 of the UNCRC and sets out how governments are expected to implement it. Specifically, in countries that adopted and ratified the UNCRC, government measures, such as legislation and policies, must ensure the complete implementation of Article 12 in recognising children as both individual and group entities.

The Committee on the Rights of the Child highlights the distinction between individual and group rights to be heard. It calls for additional measures regarding the right to be heard in educational matters for specific groups of children who are likely to experience social exclusion, such as children with disabilities or from minority groups [16]. Moreover, it sets out the steps, settings and situations for implementing the child's right to be heard. In particular, within educational settings, "Respect for right of the child to be heard ... is fundamental to the realization of the right to education" [15] (p. 24). In the case of education, children must be consulted when governments plan to introduce new policy or legislation affecting them.

The end of the 2000s ushered in a new era for learners' rights, focusing on participation and the right to be heard in all settings. In 2011, the European Commission (EC) launched An EU Agenda for the Rights of the Child [17]. This illustrates the next steps for implementing children's rights. It emphasises the need to listen to children and enable their participation in decisions that affect them.

In subsequent years, an understanding emerged that merely stating the importance of children participating in educational life is insufficient and is quite different from putting it into practice. Therefore, EU and international organisations started promoting the application of those rights, seeking countries' partnership and commitment and encouraging national governments to take action. In line with this, in 2013, the EC launched guidance for EU Member States [18] intended to ensure children's rights to participate in decision-making that affects their lives.

Around the same time, a Council of Europe Recommendation [19] advocated that children and young people participate in decisions affecting their lives, including education. The application of human rights in national policies is central in the UN Agenda for Sustainable Development [20] from 2015. The 2016 Council of Europe Strategy for the Rights of the Child underlines the importance of strengthening "opportunities for children's participation in the school setting and the democratic governance of schools by supporting the development of citizenship and human rights education in its member States" [21] (p. 13).

In line with this trend, in 2017 the Council of the EU stressed the importance of the EU co-operating with partner countries "to enhance children's ability to participate in decisionmaking and processes which concern them, at local, national, regional and international 
level, in line with article 12 of the UNCRC and General Comment 12" [22] (p. 12). Arguably, child consultation in all settings is a crucial topic for the EU and international institutions.

In keeping with previous EU policies, in spring 2021, the EC adopted a Strategy on the Rights of the Child [23] and a Proposal for a Council Recommendation Establishing a European Child Guarantee [24]. Both aim to promote and protect children's rights, tackle children's social exclusion, and provide equal opportunities, with a clear focus on access to early childhood education and care and school-based activities for at-risk children. In line with the principle of children's participation and consideration in matters directly affecting them, the EC actively involved and consulted children in developing the Strategy. It will also involve children in the Strategy evaluation in 2024.

Additionally, in 2021, the European Parliament approved a resolution on the European Child Guarantee. This was the result of a plenary debate on how the EC and the Council of the EU intend to meet the new EU target of lifting at least five million children out of poverty by 2030. The resolution specifically:

Welcomes ... that the views and suggestions of over 10,000 children have been taken on board in preparing the EU Strategy on the Rights of the Child; calls on the Commission to ensure that children's voices, as well as those of their representative organisations, are heard in the implementation and monitoring of the Child Guarantee at national, regional and local level, by enabling them to be full participants in meaningful and inclusive public dialogue and consultation and have their say on matters that concern them at EU level. [25] (p. 10).

The latest key policy development is the Conclusions on strengthening multi-level governance when promoting the participation of young people in decision-making processes. These aim to ensure that all young people have equal opportunities for participation, involvement and empowerment in relevant decision-making processes at all levels [26].

The educational environment is one setting where learners' participation and empowerment can start or work in synergy with other environments. The latest policy developments (Appendix A contains a chronological list of all key international and EU policy documents related to children's rights and voices.) show that children's participation in all fields of their lives is pivotal in building future societies that promote and nurture principles and values from the earliest life stages and throughout childhood and youth.

\section{Unlocking the Potential of Learners' Voices in Decision-Making Processes}

Although the concept of learners' voices has been debated and recognised widely, actually exercising learners' right to be heard is still high on the EU policy agenda. Over 30 years after the UNCRC came into force and 12 years on from the Charter of Fundamental Rights of the European Union becoming legally binding, EU and international policymakers perceive young people in all life settings as a resource for society and all policy contexts [27].

However, to fully empower learners' voices, different policies must be aligned-not just educational ones. Furthermore, the collaboration of different stakeholders and environments is required. The above-mentioned policy statements and tools should be relevant for countries, but their implementation mostly depends on national and local legislators and administrators. This is one reason why children's participation in community life in the education field is an uneven and gradual process across countries.

In 2012, the EC's Directorate-General for Justice commissioned an Evaluation of legislation, policy and practice on child participation in the EU [28]. This study, carried out in $28 \mathrm{EU}$ countries (at the time), sets out several key points about children's participation in educational life: undoubtedly, children play a valuable role in influencing policies, especially ones regarding education in local sectors and settings.

Even though specific legal provisions about Article 12 of the UNCRC in relation to education were in place in all EU Member States when the study was conducted, the question of scale emerged as a crucial one: at local level and in countries with a longer history of democratic participation, learners managed to have an impact mainly 
through youth and school councils and small-scale local planning decisions. At regional and national levels, children's participation in educational life had less impact and was mostly linked to formal tools and mechanisms (Ombudsman or other officials; time-bound consultative participation). Although children said that education was the most important area where they would like to express their opinions, the study found that they did not feel listened to and that they thought adults still dominated decision-making [28].

A Save the Children study from 2011 had already highlighted that:

... the right to be heard and taken seriously remains elusive for most children across the world. And even where it is implemented, it is often only in limited aspects of a child's life and largely through short-term projects and programmes. Full implementation of Article 12 continues to be impeded by many long-standing practices, cultures and attitudes, and by political and economic obstacles. [16] (p. 4).

More recent publications [29-31] show that European countries have made progress in implementing children's rights, embedding their perspectives in policy-making and improving their participation in community life. Studies in developing countries underline the need to investigate and monitor developments in this area. The gap between legislation and practice persists, so unlocking legislative and policy documents' full potential with regards to learner voice requires cross-sectoral engagement and robust, well-developed democratic institutions.

In this context, the European Youth Forum-which advocates and acts in the field of youth policy and rights-is an example of an international umbrella organisation that represents millions of young people all over Europe. It combats discrimination and exclusion by identifying challenges and monitoring policies, using a rights-based approach in all fields and promoting youth participation to remove barriers and create equal opportunities. The Youth Forum advocates quality education:

Quality formal and non-formal education and informal learning should be an inclusive space where all young people have the same opportunities and can learn, debate, fail, risk, and exchange ideas without the fear of being left behind. [32] (p. 4).

Despite the existence of active advocates for youth voices, the UN Committee on the Rights of the Child invites States Parties to promote participation and consultation in decision-making affecting young people. Awareness and understanding of those rights are fundamental if they are to be exercised.

This is also one of the topics emerging from the 2018 report "Children Human Rights Defenders", which captures the views, perspectives and recommendations of children around the world [33]. Most children who replied to the report survey perceive themselves as children human rights defenders (CHRDs). However, there are challenges that impede their action as CHRDs. These include: children are not informed about their rights; they believe they are not taken seriously; they feel unsafe acting as CHRDs because of bullying, teasing, etc.; in some cases, they are unable to act as CHRDs due to a lack of time or money (ibid.).

It appears that the effectiveness of learners' voices and engagement relies on changes in political and cultural practices that will empower learners to become active and dynamic stakeholders.

\section{Agency Work on Listening to Learners' Views on Inclusive Education}

Policy developments concerning learners' voices result from a long debate and process of including learners in policy- and decision-making. This process has been gradual and divergent in countries all over the world. From the outset it has been full of gaps, improvements and adjustments to both policy and practice. Against this backdrop of uneven progress towards considering learners' voices, since 2003 the Agency has been including learners as active stakeholders in its activities. Actively involving learners and 
considering their opinions on educational matters has been and continues to be a mainstay of Agency work, as the following sections show.

\subsection{European Hearings}

The Agency has organised four European Hearings that aimed to listen to the voices of learners and empower them by promoting their involvement in inclusive education policy debates. Two Hearings took place at the European Parliament in Brussels (2003 and 2011). One was held at the Portuguese Parliament, in co-operation with the Portuguese Ministry of Education and the Portuguese Presidency of the Council of the EU, in 2007. The fourth took place in 2015 in co-operation with the Luxembourg Presidency of the Council of the EU and the Luxembourg Ministry of Education, Children and Youth.

In total, over 300 young delegates (with and without special educational needs and/or disabilities) participated in the four Hearings, alongside national and European policymakers and professionals. The delegates were from secondary, vocational and higher education, aged between 15 and 28, and from all Agency member countries. All the Hearings included working groups of young people. These gave them the opportunity to discuss their views on how inclusive education is implemented in their educational settings, the main challenges faced and their suggestions for improvement.

In the first three Hearings, the learners expressed several ideas, opinions and proposals addressed to policy-makers and practitioners. They can be grouped into five themes:

- Rights related to non-discrimination, respecting diversity, receiving a quality education, equality of opportunity in education and having a good social and working life:

"Inclusive education should be about breaking down barriers".

- Benefits related to inclusive education, such as acquiring social skills, becoming stronger and more independent and combating discrimination and stereotypes:

"It is good for us, good for them. It is important to recognise the benefits to everyone in the class. Inclusive education helps mainstream children to become more tolerant, with more open minds".

"I think we have to study together, because in society we are also together. If we share the education together, we already learn how to live together".

- Requisites for inclusive education, such as access issues, teachers' new role in being prepared for inclusion and being responsible for all learners, and special schools' new role in supporting the mainstream sector:

"Everybody should have the chance to take part in all the classes, teachers should help to make this possible. The teacher should facilitate so you can take part in activities in and outside the classroom".

"It is important to build values in the class. Teachers have to make it a common view that nothing is 'abnormal' and everyone has the same values".

- Achievements related to well-established support systems and related funding mechanisms, as well as mobility and accessibility issues. Disability is more visible in society:

"We don't want too much focus on what we cannot do but on what we can do".

- Pending issues related to barriers that must be removed so all learners can reach local educational settings, easily access them and move around inside them; educational staff being better prepared for inclusive education, etc.:

"People with disabilities need to have the possibility to participate in society equally with anybody else. This requires accessible transport, public buildings accessible for all, including schools".

The results of the 2007 Hearing in Portugal formed the basis for the "Lisbon DeclarationYoung People's Views on Inclusive Education" [34], which constitutes core content in scholarship about inclusive education and human rights (see, for example, De Beco, Quinlivan and Lord [35]). 
In 2015, the Luxembourg Presidency of the Council of the EU hosted the Agency's fourth Hearing. It aimed to "give the word" to young people to discuss how their schools implement inclusive education. Seventy-two young people took part. Delegates from previous Hearings also participated as working group moderators and rapporteurs.

Six working groups were organised. The aim was to give all participants the opportunity to reflect and present their perspectives on five questions sent to them in advance, and to discuss and identify progress in the implementation of inclusive education policies and practice since the first Hearing in 2003. The focus was on how schools remove physical barriers and support learners in education; how classmates and teachers take all learners' needs into account; how the remaining barriers can be overcome, so that inclusion benefits all learners; and examples of organisations of young people with disabilities that influence politics and decision-making in different countries.

Discussions were in line with and built upon the main outcomes of the previous Hearings. Young people expressed their overall satisfaction with their education. However, they also identified shortcomings and formulated several concrete messages and proposals highlighting the need to take action for inclusive education.

The proposals were summarised and formed the basis for the "Luxembourg Recommendations" [36] presented at a Council of the EU meeting in November 2015. The recommendations aimed to support the implementation of inclusive education as the best option where the necessary conditions exist. They are grouped around five messages:

1. "Everything about us, with us" concerns young learners' direct involvement in all decision-making concerning them.

As the learners pointed out:

"Learners with disabilities should be listened to and their wishes taken into account".

"It is very important that parents are involved in decisions concerning their children".

"Establish student council to allow students to give their opinion on plans".

"There is a need to include the young people (with special educational needs) in policy-making on every level, from the government down to the everyday practice".

2. "Barrier-free schools" relates to eliminating all physical and technical barriers.

Although there has been much progress, there is a need to remove all barriers so all learners can easily reach, access and move around inside local educational settings. Suitable technical aids and educational materials should be available to meet individual needs.

The young people highlighted:

"Government/municipality should fully cover expenses for transportation, should be flexible".

"School environment has to be adapted (emergency exit, doors, lift, induction loops, adapted transports)".

"No separate buildings and classes, so we can help each other".

3. "Breaking down stereotypes" is about the concept of "normality". As a learner pointed out: "If we accept that everybody is different, then who is 'normal'?".

Providing teachers, school staff, young people, families and support services with reliable information on learners' different needs is key for fostering mutual respect and tolerance. Diversity must be perceived as positive; a shared value must be "to see disability as normal".

Young delegates have indicated that:

"Society needs to be more aware and more tolerant to people with disability".

"Anti-discrimination and anti-bulling training would help".

"More respect and understanding from teachers is needed. Students with special needs should not feel like outcasts. All children must be made to feel part of the group".

"More common activities, between students with and without disabilities should be organised to get to know each other and support mutual tolerance and respect from young age and it will get easier and easier later on". 
4. This centres upon a slogan some young people use: "Diversity is the mix, inclusion is what makes the mix work":

Everyone should focus on what can be done, not on what cannot be done. Education must be fully accessible, respecting the needs of all learners as the basis for quality education for all. Co-operation among teachers and other professionals, and the necessary human and/or technical support from teachers and classmates, is crucial.

The learners expressed their opinions in the discussion:

"We should be considered for what we do and not for what we look like".

"There are teachers who believe that if we are deaf or have a disability, we are less important than the other students. They should be educated. Be aware that we are just the same as anyone else".

"The attitude of the teacher helps a lot ... My classmates joke about my blindness and it helps and makes people more relaxed. Why do people bully? They don't mean to do it on purpose; I have to learn to not take it seriously".

5. "Becoming full citizens" relates to the impact of inclusive education in being fully included in society:

Learners emphasised that inclusion in mainstream schools fosters social inclusion. The aim is that all learners are able to find their place in society.

The learners expressed the following ideas:

Everybody should have a chance to take part in all the classes and the teachers should help to make this possible, so it will be a lot easier when we enter the labour market ... It is crucial for us to be included in mainstream schools in order to be included in society.

The "Inclusive Education: Take Action!" video about the Luxembourg Hearing in 2015 was selected for the UN Enable Film Festival in 2016. This festival selects short disability-related films based on content that can help raise awareness of disability issues and further promote full and effective participation in society for persons with disabilities.

\subsection{Learners' Voices for Inclusive Policy Reforms}

The Agency collaborates with the EC's Directorate-General for Structural Reform Support (DG REFORM) to provide technical support to EU countries under the Structural Reform Support Programme (SRSP). Two of these SRSP activities, in Cyprus and Poland, involved consultations with learners. Both are fully funded by the EC and concern legislative educational changes regarding inclusive education.

In Cyprus, the Agency assisted the Ministry of Education, Culture, Sport and Youth in analysing the current policy framework for special needs and inclusive education. The analysis aimed to identify the framework's strengths and weaknesses. It also aimed to produce recommendations that could serve as the general principles and basis for a new bill on inclusive education.

In 2018, the SRSP team held consultation workshops and meetings with different Cypriot stakeholders, including learners, aiming to inform them and discuss the draft recommendations. The learner workshop involved a mixed group of learners with and without disabilities aged from 12 to 18 years who attended mainstream and special schools. Three were representatives of the Cyprus Children's Parliament.

Learners were asked to provide concrete comments and proposals for changes in their schools. The learners' inputs focused on raising awareness, changing attitudes and addressing other key issues of concern. According to a representative from the Children's Parliament: "The educational system is rather good, but it requires some improvement. There is a need to raise awareness on inclusive education, for both learners and professionals".

Learners from a special school raised concerns about issues of communication and racism in mainstream schools and emphasised that it is important to inform learners and raise awareness about diversity. 
Learners highlighted that fostering good relationships between teachers and learners is key. They also pointed out several issues from schools that need special attention. For example:

Bullying, poverty, parents' divorces: these are issues in schools. There was a national programme against bullying which was effective, but there is a need for psychologists in schools. The support should be continuous throughout school life. Even before interventions, professionals need to focus on early prevention; to get help from psychologists, it is necessary to find the roots of the problems.

Some learners raised concerns about the education of foreign learners and made specific proposals:

Immigration is an issue which also needs attention. They should be slowly included in mainstream classes through teaching Greek language programmes. In the meantime, they could be with other learners speaking the same language, who can help with translation.

The SRSP team considered the learners' positions when drafting the final recommendations.

The Polish SRSP work aims to support the development of new legislation to improve education quality for all learners. As part of this, the SRSP team has identified operational definitions and key concepts that will form the basis of the new law. This involved an extensive consultation process, including with learners.

A consultation to collect learners' views took place in December 2020. Four sessions were held with various age groups from pre-primary, kindergarten, primary and secondary schools (age range: 5 to 18 years). Sixteen schools, located in four different regions, took part, with a total of 120 participants.

For each session, the moderator (from the Ministry of Education) used the materials from other consultation meetings to prepare an age-appropriate document for the learners. Each session was divided into two parts: the first to get general opinions and the second to discuss possible solutions. The learners' views from these sessions are presented below.

Learners from across all age groups agreed regarding the right of all learners to education. The youngest children recognised that they learn from their friends who are different-e.g., who wear glasses, speak a different language-and that they need to help others.

Learners felt that there should be no streaming in the school system and that equal opportunity should be stressed. However, learners recognised that striving for equality of opportunity for all learners does not mean the same results for all. They acknowledged the need to adapt conditions to learner needs, particularly for those with disabilities who they felt should not be "mistreated and pointed out".

Learners felt there is an opportunity to increase awareness of learner rights in the school community and in society more widely. They stated that the role of schools should be to introduce learners to diversity and address ignorance.

In discussing transition through the education system and into adult life, learners recognised that schools have a social function and can prepare all learners for life in a diverse society.

Learners expressed a range of views on teachers and their training, seeing the perceived low competence and lack of empathy of some teachers as particular challenges. They noted the need for training for support assistants and teacher educators. One learner summed this up as follows:

"You need a teacher who, in addition to knowledge, should convey values, attitudes ... ".

Learners noted the need for changes in assessment systems to use more descriptive feedback and no grades or competitive hierarchies.

There was some disagreement about whether learners should work in teams, but all wanted better relationships between learners and teachers. Other suggestions included smaller classes and more use of technology. 
Some learners stated that each individual learner should receive personalised learning that incorporates life preparation and wider skills-not just curriculum content. They recognised the need for more flexibility in curricula and timetables and less reliance on textbooks.

Learners criticised the frequent practice of adapting content by reducing what is offered for some learners. They expressed the view that "education must be adapted to students-not the other way round" and the need to develop positive attitudes to difference. They stressed that support should be provided in a way that avoids discrimination.

Finally, learners noted that standards should not be lower for learners with disabilities; expectations and outcomes should not just focus on academic achievement.

These examples from the Agency's SRSP work highlight the potential for including learner voice in high-level decision-making processes. In both cases, learners' perspectives, along with those of all other stakeholder groups, were incorporated into the feedback to the Ministry. That is, the learners were on an equal footing with the other stakeholders. The respective Ministries of Education recognised, valued and reflected upon the learners' contributions, which facilitated the Ministries' work in developing their inclusive education systems.

\section{Recurring Messages from Learners and Key Considerations}

The work presented illustrates how the Agency has attempted to promote learner voice, by actively engaging learners in inclusive education debates and other decisionmaking processes. The messages presented align with learners' views that were collected in other Agency work on various areas of inclusive education, such as transition from school to employment [37], vocational training [38], early childhood education [39] and raising achievement [40].

In all cases, learners' contributions focused on their right to education (access), their rights in education (learning and participation) and their rights in wider society (achievement). Key messages from young people centred upon the importance of barrier-free schools and combating stereotypes to support their longer-term social inclusion and ensure they are able to become full citizens in their local communities [41]. On top of this, learners themselves challenged the concept of normality, which is tied to the long-lasting 'dilemma of difference' (Artiles, 1998; Minow, 1990; Terzi, 2005) [42-44]: 'Do we treat all students the same (similar treatment), or do we make special accommodations for certain groups (preferential treatment)? This brings into the surface the dilemma that still exists for national priorities as to whether focusing strategies and innovations on special education or on diversity in the mainstream school [45]. Although there has been a lot of progress in quality and inclusive education in recent years, as opposed to special education, learners highlighted that much remains to be done. As they put it: "Real inclusion has not been achieved yet. Real action should be taken instead of just talking" [41] (p. 21).

Despite political recognition, several issues greatly affect how young people are currently positioned and their voices incorporated within decision-making processes. As stated, major cultural changes are needed to promote learner voice and participation within inclusive education systems. Indeed, a recurring message from young learners refers to the importance of teachers and other professionals taking learners' wishes, views and opinions more seriously, providing space to listen to them and involving parents/guardians in decisions that concern learners.

This message resonates with the findings of a wide variety of learner voice studies that have highlighted the power imbalances in the adult-young person relationship [1,2,46-50] as well as the danger of representing learner voice uncritically, also known as the 'problem of authenticity' [47]. The danger of treating learners simplistically, tokenistically or-even worse-manipulatively $[48,49]$ increases when they are involved in decision-making processes. Therefore, one significant cultural change that is needed relates to how adults represent the voices of learners, especially those from vulnerable groups (such as learners 
with disabilities). Learners emphasised the need for targeted training for teachers and teacher educators to promote not just knowledge, but a true culture of listening.

Representing learners as a uniform and united entity and treating learners as having a "collective" voice is problematic. It runs the risk of overlooking essential differences among learners, their perspectives and their unique needs [50]. The view that education must be adapted to learners-and not the other way round-seems relevant here; it implies that embedding positive attitudes to difference throughout school practice might inform new ways of listening. As learners put it: "we don't want too much focus on what we can't do but on what we can do" [41] (p. 14). It is therefore essential to seek effective ways to reflect critically and interpret voices in ways "that avoid tokenism or further alienation of young people" [49] (p. 238).

Learners have consistently highlighted that participation in quality education is a human right that involves common activities and interaction of everyone involved. It appears that teachers, researchers and especially policy-makers still lack the essential knowledge or mechanisms to listen meaningfully and promote learner participation. This is closely related to the act (and the art) of listening-how can adults truly listen to learners, especially those from vulnerable groups? Ainscow and Messiou take this question further, asking: "are we prepared to listen and act on what we hear?" [51] (p. 26).

A recurring message from learners refers to the social function of schools and their key role in raising awareness around inclusion, introducing learners to diversity and addressing ignorance and discrimination. Acting upon this important message would require several strategic actions in the context of education reforms, such as prioritising awareness-raising in schools and embedding diversity issues into national curricula. Through these types of concrete actions, education authorities and professionals can become more accountable and commit to learner voice as a principle.

\section{Concluding Comments}

This article focused on how learners' voices could be considered in the development of inclusive educational policies. It first discussed the emergence of the learner voices concept within EU and international policy literature and indicated the conceptual shift in bringing the child, as an individual, into the centre of the debate. This ties in closely with the development of inclusive education as a democratic and equitable educational approach. It then documented several contributions by learners from across Europe who shared their views about inclusive education. In so doing, it highlighted key messages from learners and the potential of their meaningful participation in inclusive education debates. The article's contribution lies exactly in providing the policy context as well as showcasing recent attempts of positioning learners at the centre of inclusive policy debates at EU level.

The latest policy developments suggest that learners are key agents who can lead and influence educational decisions at a school, local, regional and national level. However, in reality, any efforts to listen to learners' voices still consist of non-intensive involvement, mainly in the forms of expression, consultation and just partial participation. Therefore, as a first step, listening to learners must continue to be supported in research, policy and practice. The next crucial step involves intensifying research studies and practical examinations that aim to identify appropriate processes and practices that do not just involve learners, but actually act upon their voices, repositioning them as lead agents of educational change and reform [50].

Andrea, an Italian learner who participated in an event organised by the Bulgarian Presidency of the Council of the EU and the Agency in 2018, pointed out:

It is not easy for us to live in a period where the values that founded the European Union are difficult to find within political choices ... There is a need to talk and confront each other. The European Union promotes cultural exchanges by allowing thousands of Europeans to travel and live throughout the Union. A European day dedicated to integration and inclusion, every year and in each school, 
would engage students in actions to disseminate what has been experienced and received thanks to European education programmes. [52] (p. 22).

In an era of uncertainty, this idea is even more important. The Agency's scoping research on the impact of COVID-19 shows that the pandemic has created one of the biggest education system crises in history, affecting access to learning, widening inequalities and limiting opportunities for the voices of the most vulnerable learners to be heard [53]. Recent evidence shows that learners had very limited participation in formulating education responses to the crisis (ibid). Yet, learners could and should be able to bring new perspectives and determine more adapted solutions to current educational realities. Including learners in education policy debates and decision-making processes not only exercises their right to be heard, but is a crucial step in developing more inclusive education systems.

Author Contributions: Supervision, A.W.; Validation, M.K.; Visualization, A.W. and M.K.; Writingoriginal draft, A.M. and A.K. All authors have read and agreed to the published version of the manuscript.

Funding: This research received no external funding.

Informed Consent Statement: Informed consent was obtained from all subjects involved in the study.

Acknowledgments: The authors gratefully acknowledge the contributions of all the learners and the Agency country representatives to the activities this article uses as its foundation. Particular thanks to Victoria Soriano, Senior Policy Consultant, European Agency for Special Needs and Inclusive Education.

Conflicts of Interest: The authors declare no conflict of interest.

\section{Appendix A}

List of key international and EU policy documents on children's rights and voices:

- $\quad$ United Nations, 1989. Convention on the Rights of the Child

- $\quad$ European Union, 2000. Charter of Fundamental Rights of the European Union

- $\quad$ United Nations Committee on the Rights of the Child, 2009. General comment No. 12 (2009): The right of the child to be heard

- European Commission, 2011. Communication from the Commission to the European Parliament, the Council, the European Economic and Social Committee and the Committee of the Regions: An EU Agenda for the Rights of the Child

- Council of Europe, 2012. Recommendation CM/Rec(2012)2 of the Committee of Ministers to member States on the participation of children and young people under the age of 18

- European Commission, 2013. Commission recommendation of 20 February 2013-Investing in Children: Breaking the Cycle of Disadvantage

- United Nations, 2015. Transforming our world: the 2030 Agenda for Sustainable Development

- $\quad$ Council of Europe, 2016. Strategy for the Rights of the Child (2016-2021)

- Council of the European Union, 2017. Revision of the EU Guidelines for the Promotion and Protection of the Rights of the Child (2017). Leave No Child Behind

- European Commission, 2021. Communication from the Commission to the European Parliament, the Council, the European Economic and Social Committee and the Committee of the Regions: EU strategy on the rights of the child

- European Commission, 2021. Proposal for a Council Recommendation Establishing a European Child Guarantee

- European Parliament, 2021. Motion for a Resolution further to Questions for Oral Answer B9-0000/2021 and B9-0000/2021 pursuant to Rule 136(5) of the Rules of Procedure on the European Child Guarantee

- Council of the European Union, 2021. Conclusions of the Council and of the Representatives of the Governments of the Member States meeting within the Council on Strengthening the multilevel governance when promoting the participation of young people in decision-making processes 


\section{References}

1. Lewis, A.; Porter, J. Interviewing children and young people with learning disabilities: Guidelines for researchers and multiprofessional practice. Br. J. Learn. Disabil. 2004, 32, 191-197. [CrossRef]

2. Robinson, C.; Taylor, C. Theorizing student voice: Values and perspectives. Improv. Sch. 2007, 10, 5-17. [CrossRef]

3. Toshalis, E.; Nakkula, M.J. Motivation, Engagement, and Student Voice: The Students at the Center Series; Jobs for the Future: Boston, MA, USA, 2012.

4. Organisation of Provision to Support. Inclusive Education—Literature Review; European Agency for Development in Special Needs Education: Odense, Denmark, 2013.

5. Kefallinou, A.; Donnelly, V.J. (Eds.) Raising the Achievement of All Learners in Inclusive Education: Lessons from European Policy and Practice; European Agency for Special Needs and Inclusive Education: Odense, Denmark, 2017.

6. Global Education Monitoring Report 2020: Inclusion and Education: All Means All; UNESCO (United Nations Educational, Scientific and Cultural Organization): Paris, France, 2020.

7. Soriano, V. Young voices on inclusive education. In Implementing Inclusive Education: Issues in Bridging the Policy-Practice Gap (International Perspectives on Inclusive Education, Volume 8); Watkins, A., Meijer, C., Eds.; Emerald: Bingley, UK, 2016 ; pp. 255-272.

8. European Agency for Special Needs and Inclusive Education. Agency Position on Inclusive Education Systems. 2015. Available online: www.european-agency.org/sites/default/files/PositionPaper-EN.pdf (accessed on 7 June 2021).

9. Declaration of the Rights of the Child; Resolution 1386 (XIV), A/RES/14/1386; United Nations: New York, NY, USA, 1959.

10. Convention on the Rights of the Child; A/RES/44/25; United Nations: New York, NY, USA, 1989.

11. Charter of Fundamental Rights of the European Union; 2000/C 364/01; European Union: Brussels, Belgium, 2000.

12. European Social Charter (Revised). European Treaty Series, No. 163; Council of Europe: Strasbourg, France, 1996.

13. European Convention on the Exercise of Children's Rights. European Treaty Series, No. 160; Council of Europe: Strasbourg, France, 1996.

14. Treaty of Lisbon Amending the Treaty on European Union and the Treaty Establishing the European Community, Signed at Lisbon, 13 December 2007. OJ C 306; European Union: Brussels, Belgium, 2007; pp. 1-271.

15. General Comment No. 12 (2009): The Right of the Child to be Heard. CRC/C/GC/12; United Nations Committee on the Rights of the Child: New York, NY, USA, 2009.

16. Save the Children. Every Child's Right to Be Heard. A Resource Guide on the UN Committee on the Rights of the Child General Comment No. 12; Save the Children: London, UK, 2011.

17. Communication from the Commission to the European Parliament, the Council, the European Economic and Social Committee and the Committee of the Regions: An EU Agenda for the Rights of the Child. COM/2011/0060 Final; Publications Office of the European Union: Luxembourg, 2011.

18. Commission Recommendation of 20 February 2013-Investing in Children: Breaking the Cycle of Disadvantage (2013/112/ EU). OJ L 59, 2.3; European Commission: Luxembourg, 2013; pp. 5-16.

19. Recommendation CM/Rec(2012)2 of the Committee of Ministers to Member States on the Participation of Children and Young People under the Age of 18; Council of Europe: Strasbourg, France, 2012.

20. Transforming Our World: The 2030 Agenda for Sustainable Development. A/RES/70/1; United Nations: New York, NY, USA, 2015.

21. Strategy for the Rights of the Child. (2016-2021); Council of Europe: Strasbourg, France, 2016.

22. Revision of the EU Guidelines for the Promotion and Protection of the Rights of the Child (2017). Leave No Child Behind. 6846/17; Council of the European Union: Brussels, Belgium, 2017.

23. Communication from the Commission to the European Parliament, the Council, the European Economic and Social Committee and the Committee of the Regions: EU Strategy on the Rights of the Child. COM/2021/142 Final; Publications Office of the European Union: Luxembourg, 2021.

24. Proposal for a Council Recommendation Establishing a European Child. Guarantee. COM/2021/137 Final; Publications Office of the European Union: Luxembourg, 2021.

25. Motion for a Resolution Further to Questions for Oral Answer B9-0000/2021 and B9-0000/2021 Pursuant to Rule 136 of the Rules of Procedure on the European Child Guarantee. 2021/2605(RSP); European Parliament: Brussels, Belgium, 2021.

26. Conclusions of the Council and of the Representatives of the Governments of the Member States Meeting within the Council on Strengthening the Multilevel Governance when Promoting the Participation of Young People in Decision-Making Processes. 8169/1/21; Council of the European Union: Brussels, Belgium, 2021.

27. Resolution of the Council of the European Union and the Representatives of the Governments of the Member States Meeting within the Council on a Framework for European Cooperation in the Youth Field: The European Union Youth Strategy 2019-2027. 2018/C 456/01; Council of the European Union: Brussels, Belgium, 2018.

28. European Commission. Evaluation of Legislation, Policy and Practice on Child Participation in the European Union (EU); Publications Office of the European Union: Luxembourg, 2015.

29. European Commission. Embedding a Children's Rights Perspective in Policy and Decision-Making; Publications Office of the European Union: Luxembourg, 2019.

30. For Every Child, Every Right: The Convention on the Rights of the Child at a Crossroads; UNICEF (United Nations Children's Fund): New York, NY, USA, 2019.

31. Every Child Learns. UNICEF Education Strategy 2019-2030; UNICEF: New York, NY, USA, 2019.

32. Resolution. EU Youth Strategy. GA 0233-16_FINAL; European Youth Forum: Brussels, Belgium, 2016. 
33. Children Human Rights Defenders. The Views, Perspectives and Recommendations of Children across the World; Child Rights Connect: Geneva, Switzerland, 2018.

34. Lisbon Declaration-Young People's Views on Inclusive Education; European Agency for Development in Special Needs Education: Odense, Denmark, 2007.

35. De Beco, G.; Quinlivan, S.; Lord, J.E. (Eds.) The Right to Inclusive Education in International Human Rights Law; Cambridge University Press: Cambridge, UK, 2019.

36. Luxembourg Recommendations; European Agency for Special Needs and Inclusive Education: Odense, Denmark, 2015.

37. Individual Transition Plan: Supporting the Move from Schools to Employment; European Agency for Development in Special Needs Education: Odense, Denmark, 2006.

38. European Patterns of Successful Practice in Vocational Education and Training-Participation of Learners with SEN/Disabilities in VET; European Agency for Development in Special Needs Education: Odense, Denmark, 2013.

39. Kyriazopoulou, M.; Bartolo, P.; Björck-Åkesson, E.; Giné, C.; Bellour, F. (Eds.) Inclusive Early Childhood Education: New Insights and Tools-Contributions from a European Study; European Agency for Special Needs and Inclusive Education: Odense, Denmark, 2017.

40. Donnelly, V.; Kefallinou, A. (Eds.) Key Actions for Raising Achievement: Guidance for Teachers and Leaders; European Agency for Special Needs and Inclusive Education: Odense, Denmark, 2018.

41. Take Action for Inclusive Education: Delegates' Reflections and Proposals; European Agency for Special Needs and Inclusive Education: Odense, Denmark, 2016.

42. Artiles, A.J. 'The dilemma of difference: Enriching the disproportionality discourse with theory and context. J. Spec. Educ. 1998, 32, 32-36. [CrossRef]

43. Minow, M. Making All the Difference: Inclusion, Exclusion, and American Law; Cornell University Press: Ithaca, NY, USA, 1990.

44. Terzi, L. Beyond the dilemma of difference: The capability approach to disability and special educational needs. J. Philos. Educ. 2005, 39, 443-459. [CrossRef]

45. Vislie, L. 'From integration to inclusion: Focusing global trends and changes in the western European societies'. Eur. J. Spec. Needs Educ. 2003, 18, 17-35. [CrossRef]

46. Robinson, C.; Taylor, C. Student voice as a contested practice: Power and participation in two student voice projects. Improv. Sch 2013, 16, 32-46. [CrossRef]

47. Spyrou, S. Researching children's silences: Exploring the fullness of voice in childhood research. Childhood 2016, $23,7-21$. [CrossRef]

48. Messiou, K.; Hope, M.A. The danger of subverting students' views in schools. Int. J. Incl. Educ. 2015, 19, 1009-1021. [CrossRef]

49. Mitra, D.L. Balancing power in communities of practice: An examination of increasing student voice through school-based youth-adult partnerships. J. Educ. Chang. 2008, 9, 221-242. [CrossRef]

50. Cook-Sather, A. Sound, Presence, and Power: Exploring the metaphor of student voice in educational research and practice. Curric. Inq. 2006, 36, 359-390. [CrossRef]

51. Ainscow, M.; Messiou, K. Engaging with the views of students to promote inclusion in education. J. Educ. Chang. 2017, 19, 1-17. [CrossRef]

52. Soriano, V.; Hughes, G. (Eds.) Promoting Common Values and Inclusive Education: Reflections and Messages; European Agency for Special Needs and Inclusive Education: Odense, Denmark, 2018.

53. Popescu, C. (Ed.) The Impact of COVID-19 on Inclusive Education at the European Level: Literature Review; European Agency for Special Needs and Inclusive Education: Odense, Denmark, 2021. 